\title{
Nature fights back
}

In thinking about the state of the global environment, or of humankind's faltering efforts to preserve it, I experience occasional bouts of optimism - typically buoyed by some new technology or the enthusiasm of youthful activists. These are then punctuated by episodes of gloom brought on by facts about current reality. The news on the state of nature isn't all negative. A lot of it is.

Last year, the insurance giant Swiss Re released a report (Biodiversity and Ecosystem Services; Swiss Re Institute, 2020) assessing the state of the global environment. Analysing measures for water and soil quality, biodiversity, and many other factors, it concluded that roughly one nation in five faces the threat of near-future ecosystem collapse, which would erase more than $50 \%$ of their economic activity, and destroy much of their capacity to recover. In the past two decades, globally, we've lost some 500 million acres of forest.

Any naturalist or environmentalist regards such news as a profound tragedy, quite apart from any reckoning of the utilitarian or economic value lost to humanity. One can value the inherent beauty in nature - as Fiona Reynolds has argued in her moving book The Fight for Beauty (Oneworld Books, 2017) - even if this conception has temporarily lost favour in our contemporary economics-oriented society.

We should remember, however, just how short-sighted the degradation of nature is even from a strictly selfish human point of view, as we risk wasting an immense storehouse of scientific information and value. If this isn't obvious, the past 18 months of the COVID-19 pandemic offer several poignant reminders.

The most accurate of the many tests for the coronavirus infection - so-called PCR tests - work by detecting fragments of the virus's genetic material. These tests, familiar to anyone carrying out crucial public health tasks or still engaged in international travel, rely on an unusual enzyme discovered in a bacterium, Thermus aquaticus, which thrives in temperatures of $170^{\circ} \mathrm{F}$ or more. That enzyme - - the Taq polymerase underlies the polymerase chain reaction (PCR), a technique that allows scientists to amplify one tiny fragment of DNA into many identical copies.

This peculiar enzyme enables the DNA analysis behind forensic criminology, DNA tests for tracing human ancestry and innumerable techniques for diagnosing and treating diseases. None of this

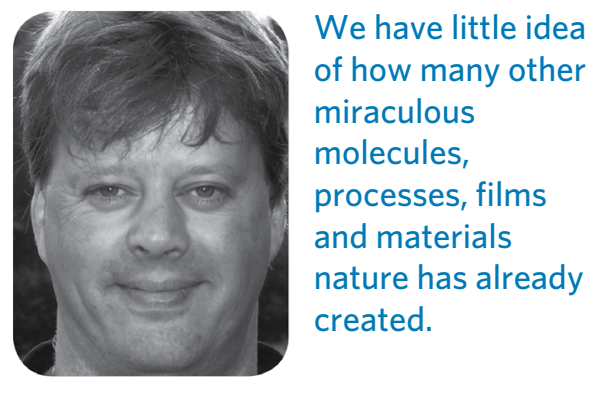

3, 929-937; 2020) found that plants may be able to take up plastics from polluted soils, bringing plastics into our food.

Yet one of the most promising ways to start reducing plastics pollution lies in recycling technologies based around chemistry inspired by biology. Some bacteria have evolved an enzyme that lets them digest cutin, the waxy substance that makes plant leaves waterproof. This enzyme, it turns out, also catalyses the breakdown of plastic - in particular, the plastic (polyethylene terephthalate, PET) used ubiquitously in packaging. A study from earlier this year found a way to engineer an improved version of an enzyme that outperforms all known PET digestive enzymes by a long margin (V. Tournier et al. Nature 580, 216-219; 2021).

This is another example of why it makes good sense to preserve nature and the technological clues it holds. Of course, these examples could be multiplied. We have little idea of how many other miraculous molecules, processes, films and materials nature has already created, all far beyond our current technology. I suspect our imagination probably errs conservatively, vastly underestimating the richness of what's around us.

We have history, after all. Many leading physicists thought we'd discovered most of the fundamental laws of physics by 1900 - just before we learned about relativity, quantum theory and the expanding Universe. A few decades ago, most biologists were convinced we had a generally complete understanding of heredity and development: we knew about genes, and their dominant influence through the so-called central dogma of molecular biology, according to which genetic information in the DNA alone dictates protein structures and gene regulation through transcription and translation. Yet an extremely diverse range of epigenetic influences - including RNA interference, gene silencing and DNA methylation, all then unimagined - have proven absolutely essential to basic processes of biological function.

This is one thing we really should learn - the world always reveals itself to be richer and more complex than we had once expected.

\section{Mark Buchanan} and on and in the bodies of most animals and insects. Once in the environment, plastic stays around for hundreds of years. A recent study (L. Li et al. Nature Sustainability
Published online: 12 July 2021

https://doi.org/10.1038/s41567-021-01295-Z 